\title{
Experimental infection of six North American fish species with the North Carolina strain of Spring Viremia of Carp Virus
}

Eveline J. Emmenegger ${ }^{\mathrm{a}^{*}}$, George E. Sanders ${ }^{\mathrm{b}}$, Carla M. Conway ${ }^{\mathrm{a}}$, Fred P. Binkowski ${ }^{\mathrm{c}}$, James R. Winton ${ }^{\mathrm{a}}$, and Gael Kurath ${ }^{\mathrm{a}}$

${ }^{a}$ Western Fisheries Research Center, Dept. of the Interior, US Geological Survey, 6505 NE 65th Street, Seattle, Washington 98115 USA

${ }^{\mathrm{b}}$ University of Washington, School of Medicine, Dept. of Comparative Medicine, T-160 Health Sciences Center, Seattle, Washington 98195 USA

${ }^{c}$ University of Wisconsin-Milwaukee, School of Freshwater Sciences, 600 E. Greenfield Ave., Milwaukee, Wisconsin 53204 USA

*Corresponding author at: Western Fisheries Research Center, Department of the Interior, US Geological Survey, 6505 NE 65th Street, Seattle, Washington 98115 USA

Tel.: (206) 526-2276

Email address: eemmenegger@usgs.gov

Spring viremia of carp virus (SVCV) is a rhabdoviral pathogen associated with disease outbreaks in cultured and wild fish worldwide. Common carp (Cyprinus carpio carp), and koi (C. carpio koi) suffer the highest mortalities from SVCV infections, while other cyprinid fish species have varying susceptibility. Although salmonid fish typically are considered refractory to infection by SVCV, there have been a few reports suggesting infection has occurred in rainbow trout (Oncorhynchus mykiss). There have been no reports of Percid fish being infected with SVCV. Since the first North American outbreak of SVCV at a North Carolina koi farm in 2002 there have been eight subsequent detections or outbreaks of SVCV among fish species from the families of Cyprinidae and Centrarchidae within the US and Canada. Thus, this exotic virus is considered a potential threat to native and cultured fish populations in North America. We performed multiple experimental challenges with fish species from three families (Salmonidae, Cyprinidae, and Percidae) to identify the potential risk associated with SVCV exposure of resident fish populations in North America. 
Three salmonid species, rainbow and steelhead trout (O. mykiss), Chinook salmon (O. tshawytscha), and sockeye salmon (O. nerka), were challenged by immersion or injection with the North Carolina SVCV isolate. Two cyprinid species, koi and fathead minnow (Pimephales promelas) and one percid species, yellow perch (Perca flavescens) were also challenged. Koi were highly susceptible to SVCV up to 11 months of age and fathead minnows had chronic disease expression with moderate mortality (29\%). SVCV also induced moderate mortalities $(33 \%)$ in yellow perch fry. Virus challenged salmonid fish had cumulative percent mortalities ranging from 0 to $100 \%$, with sockeye salmon fry being the most vulnerable. A sub-sample of mortalities and survivors were screened for virus by plaque assay and reverse transcription polymerase chain reaction. In general, all mortalities tested positive for SVCV with high viral titers while survivors had variable persistence of SVCV with overall lower virus titers. Our SVCV challenges of multiple North American fish species suggested that host age is a key factor in determining disease outcome. Other factors, such as fish broodstock, virus strain, water temperature, and rearing conditions in association with the intrinsic level of species susceptibility may also impact infection dynamics. This is the first report of SVCV infecting a species (yellow perch) in the family Percidae and that sockeye salmon fry can suffer similarly high mortalities as the primary SVCV host species.

Key Words: Spring viremia of carp virus (SVCV), salmon, perch, susceptibility, exotic virus, host adaptation 


\section{Introduction}

Spring viremia of carp (SVC) is one of 8 fish virus diseases worldwide that requires immediate notification to the World Organization for Animal Health (Office International des Epizooties, OIE) when detected in new species or geographic area (OIE 2015).

Disease outbreaks in wild and propagated common carp Cyprinus carpio carpio have historically been reported from countries in Europe in association with high density fish kills and devastating economic losses (Fijan, 1999). As its name suggests, SVC typically occurs during spring and summer seasons in conjunction with rising water temperatures (Ahne et al., 2002). The causative agent, spring viremia of carp virus (SVCV) is a rhabdovirus with an $11 \mathrm{~kb}$ genome consisting of 5 protein-encoding genes, N, P, M, G, and L (Björklund et al., 1996). Based on phylogenetic analyses of P and G-gene sequences, SVCV isolates can be divided into 4 genotypes, Ia, Ib, Ic, \& Id with geographic associations (Stone et al., 2003; Miller et al., 2007; Warg et al., 2007).

Common carp is the primary host of SVCV and the ornamental variant, koi C. carpio $k o i$, is also considered highly susceptible to SVCV infection (Fijan et al., 1971; Ahne et al., 1998). In addition to common carp and koi, there have been disease incidences or natural infections in other fish species within the family Cyprinidae. Carp-like cyprinids known to have been infected both naturally and experimentally with SVCV include: bighead carp Hypopthalmichthys nobilis (Shchelkunov \& Shchelkunova, 1989), crucian carp Carassius carassius (Kölbl, 1975; Miller et al., 2007), grass carp Ctenopharyngodon idella (Shchelkunov and Shchelkunova, 1989; Haenen and Davidse, 1993), and silver carp Hypophthalmichthys molitrix (Shchelkunov et al., 1984; Shchelkunov and 
Shchelkunova, 1989; Saad et al., 2008; Gado et al., 2015). Natural infections of three Indian carp species; rohu Labeo rohita, merigal Cirrhinus merigala, and catla Catla catla have also been described (Asl et al., 2008a). Non-carp-like cyprinid species that have been naturally infected with SVCV include: orfe/ide Leuciscus idus (Dixon et al., 1994; Miller et al., 2007), tench Tinca tinca (Dixon et al., 1994; Miller et al., 2007), and goldfish Carassius auratus (Jørgensen et al., 1989; Alexandrino et al., 1998; Liu et al., 2005; Miller et al., 2007). Pathogenicity of the virus in goldfish was also demonstrated via experimental challenges (Alexandrino et al., 1998; Goodwin, 2002). SVCV infections of cyprinid species by experimental exposure alone have been confirmed for Caspian white fish Rutilus frisii kutum (Ghasemi et al., 2014; Zamani et al., 2014), common roach Rutilus rutilus (Haenen and Davidse, 1993), golden shiner Notemigonus crysoleucas (Goodwin, 2002), and zebrafish Danio rerio (Sanders et al., 2003).

Isolation of SVCV from fish species of other families, after natural infections and/or experimental exposure, has been reported in Nile tilapia Oreochromis niloticus (Cichlidae; Soliman et al., 2008; Gado et al., 2015), Northern pike Esox lucius (Esocidae; Ahne, 1985; Koutná et al., 2003; Vicenova et al., 2011), Siberian sturgeon Acipenser baerii (Acipenseridae; Vicenova et al., 2011), sheatfish Silurus glanis (Siluridae; Fijan et al., 1984; Jørgensen et al., 1989; Pasco et al., 1987), guppy Poecilia reticulata (Poeciliidae; Ahne, 1973; Bachmann and Ahne, 1974), and rainbow trout Oncorhynchus mykiss (Salmonidae; Stone et al., 2003; Jeremić et al. 2006; Asl et al. 2008b). Natural outbreaks in bluegill Lepomis macrochirus and largemouth bass Micropterus salmoides, both members of the family Centrarchidae, have also recently been described (Phelps et al., 2012). Another centrachid species pumpkinseed Lepomis gibbosus is frequently cited 
as being susceptible by experimental infection, however the original data supporting this claim appears to be unavailable (OIE, 2012). Information regarding the relative susceptibility of these non-cyprinid fish species to SVCV is limited.

The first reported detection of SVCV in North America was in 2002. Initially from a disease outbreak at a North Carolina koi farm in the spring (Goodwin, 2002) and later from an epizootic occurring in wild common carp at Cedar Lake, Wisconsin (Dikkeboom et al. 2004). From 2003 to 2007 the virus was detected in carp or koi in the States of Illinois, Washington, Wisconsin, and Missouri, and in Ontario, Canada (Garver et al., 2007, Warg et al., 2007) and from 2008 to 2011, outbreaks occurred not only in carp species, but were reported for the first time in the centrachids bluegill and largemouth bass from the States of Wisconsin, Ohio, and Minnesota (Phelps et al., 2013). North American isolates of SVCV since 2002 have all been molecularly characterized as Ia genotypes. However, Id subtypes were linked to putative SVCV isolations from shrimp (Penaeus stylirostris and Penaeus vannamei) in Hawaii (Johnson et al., 1999) and archived histology samples from a wild common carp die-off that occurred in 1989 in the Petenwell Flowage of the Wisconsin River (USA) (Marcquenski et al., 2003; Miller et al., 2007).

It has been suggested that many of the SVCV isolations and outbreaks in North America are linked to fish importation events from foreign countries (Ariel, 2005; Miller et al., 2007; Ubeyratne and Jayaweera, 2013). Introduction and subsequent establishment of non-native fish species along with hitchhiker pathogens are likely to continue with the parallel risk of exotic pathogen transmission to cultured or wild native fish populations. Thus, investigation of the susceptibility of native species to introduced pathogens is 
essential to manage future outbreaks that may occur with emerging pathogens, such as SVCV (Tompkins et al., 2015). We performed multiple experimental challenges using the 2002 North Carolina SVCV isolate in fish species from three families (Salmonidae, Cyprinidae, and Percidae), with fish of various ages, to obtain an initial assessment of the potential risk SVCV exposure might pose for resident fish populations in North America.

\section{Materials and methods}

\subsection{Fish Species Tested}

Fish were transported to the Western Fisheries Research Center (WFRC) in Seattle, Washington (WA) where they were housed in separate circular tanks with aeration in single-pass, sand-filtered, and UV-treated freshwater from Lake Washington. All stocks were segregated and quarantined upon arrival, and remained healthy until the initiation of each challenge experiment. The protocols for rearing and experimental use of live animals were approved by the Institutional Animal Care and Use Committee (IACUC) of the WFRC under the guidelines provided by the Guide for the Care and Use of Laboratory Animals (NRC 2011).

\subsubsection{Salmonids}

Three salmonid species, sockeye salmon Oncorhynchus nerka, Chinook salmon $O$. tshawytscha, and rainbow trout and steelhead trout $O$. mykiss, were tested in susceptibility challenges. One month-old Cedar River sockeye salmon fry obtained from the Washington Department of Fish \& Wildlife (WDFW) and Seattle Public Utilities 
Cedar River Hatchery Program were reared at a water temperature of $10^{\circ} \mathrm{C}$ until challenge. Fertilized eggs of the Chinook salmon Green River stock were transferred from the WDFW Soos Creek Hatchery (Auburn, WA) and were incubated at ambient lake water temperatures $\left(7.0-9.0^{\circ} \mathrm{C}\right)$ until hatch. After buttoning up, fry were moved to tanks with $12^{\circ} \mathrm{C}$ water. Research grade rainbow trout $O$. mykiss fry, approximately 0.5 months old, were received from Clear Springs Foods Inc. (Buhl, Idaho) and $\sim 1$ month old steelhead trout $O$. mykiss transferred from the WDFW Tokul Creek Hatchery (Fall City, WA) were reared in tanks with water temperatures of $15^{\circ} \mathrm{C}$. All salmonids were initially fed daily a soft Bio-Clark Starter crumble diet (Bio-Oregon, Longview, WA) and then switched to the BioClark $1.5 \mathrm{~mm}$ pellets at approximately 2 months of age.

\subsubsection{Percids}

Captively propagated yellow perch Perca flavescens fry of the Choptank River and Sassafras River stocks, both originating from Chesapeake Bay, Maryland, and Perquimans River stock from Albemarle Sound, North Carolina, were acquired from the University of Wisconsin-Milwaukee School of Freshwater Sciences (Milwaukee, Wisconsin). Fish weighing approximately $1.0 \mathrm{~g}$ at arrival were reared at temperatures ranging from $11-13{ }^{\circ} \mathrm{C}$ and fed Skettering (Tooele, Utah) extruded sinking salmon pellets every other day. Sassafras yellow perch fry, and Perquimans and Choptank River yearlings were used in the SVCV challenge experiments.

\subsubsection{Cyprinids}

Two cyprinids, fathead minnow Pimephales promelas and koi Cyprinus carpio koi, were used in the SVCV experimental exposure studies. Fathead minnows sent from the University of Arkansas Department of Aquaculture and Fisheries (Pine Bluff, Arkansas) 
arriving at approximately 5 months of age were held at a water temperature of $11.5^{\circ} \mathrm{C}$ and fed every other day a Bio-Oregon $2.0 \mathrm{~mm}$ pellet. Koi fry approximately 1-month old were transferred from the Pan Inter Corp breeding facility (Kenmore, WA) to the WFRC wet laboratory and reared at water temperatures ranging from $17-19^{\circ} \mathrm{C}$. Koi were fed every other day with a mixed feed diet of moist and dry pellets consisting of Life Stage Diet Food (Bio-Oregon), Wardley Pond 10 (Hartz Mountain Co., Secaucus, NJ), and Hikari Gold (Kyorin Food Industries, Japan) with pellet size increasing as the koi aged.

\subsection{Virus Propagation}

The first North American isolate of SVCV (Goodwin 2002) was used in all challenge experiments. Monolayers of epithelioma papulosum cyprini (EPC) cells (Fijan et al. 1983; Winton et al. 2010) were grown at $20^{\circ} \mathrm{C}$ until confluent following the methods of Emmenegger and Kurath (2008). Infected cell supernatant, harvested at 90\% cytopathic effect, was spun at $1,000 \times \mathrm{g}$ for $10 \mathrm{~min}$ to pellet debris. The supernatant from this third passage of virus was collected and frozen as aliquots at $-80^{\circ} \mathrm{C}$ until challenge. Virus concentrations for the challenge inoculua were determined by plaque assay using the protocols described by Batts and Winton (1989), but with a higher incubation temperature of $20^{\circ} \mathrm{C}$.

\subsection{SVCV challenge experiments}

Specific weights and ages of the various fish species at the beginning of each challenge experiment are listed in Table 1. On the day of challenge, fish were transferred from the WFRC main wet lab to aquatic biosafety level 3 laboratory (BSL-3) tanks at 
water temperatures of $9-10^{\circ} \mathrm{C}$. Duplicate groups of all salmonid stocks (10 fish/tank) and fathead minnows (25 fish/tank), and triplicate groups of yellow perch (30 fish/tank) were tested in the various challenge experiments. The number of koi, serving as positive (susceptible) control species, used in each challenge experiment matched the number of replicate tanks of target test fish species used in each particular experiment, with exception of the last yellow perch challenge at which time there were no koi available.

\subsubsection{Virus exposure by immersion}

Immersion exposures occurred in $3 \mathrm{~L}$ of static aerated water at a virus concentration of $1.0 \times 10^{5} \mathrm{PFU} / \mathrm{mL}$ for 1 or $2 \mathrm{~h}$, after which continuous water flow to the $30 \mathrm{~L}$ tanks was restored. For the mock treatments, a matching number of fish for each species were subjected to the same procedures except they were immersed in water containing an equivalent volume of virus-free culture media.

\subsubsection{Virus exposure by injection}

For injection treatments, fish were intraperitoneally (IP) injected after being anesthetized with $0.12 \mathrm{~g}$ of tricaine methanesulfonate (MS-222; Argent Chemical Laboratories, Redmond, Washington) and $0.60 \mathrm{~g}$ of $\mathrm{NaHCO}_{3}$ (Sigma-Aldrich, St. Louis, Missouri) in $2 \mathrm{~L}$ of freshwater. After IP injection with $100 \mu \mathrm{L}$ of cell culture medium containing virus at one of the three doses: $5.0 \times 10^{5} \mathrm{PFU}, 6.5 \times 10^{5} \mathrm{PFU}$, or $1.0 \times 10^{6} \mathrm{PFU}$ of SVCV per fish, the injected fish were placed into recovery buckets containing $2 \mathrm{~L}$ of freshwater and then transferred to holding tanks containing flow-through water. Mock treatments, for each species/stock with an equivalent number of fish and tanks, consisted of injections of virus-free cell culture media of the same volume.

\subsubsection{Challenge parameters}


At the start of each injection or immersion challenge, water temperature ranged between $9.0-10.0^{\circ} \mathrm{C}$ and then was raised $0.5^{\circ} \mathrm{C} /$ day until it reached $12-13^{\circ} \mathrm{C}$ and held constant for the duration of the experiment. All fish in the treatment tanks for mortality assessment were monitored daily for morbidity, and fed every other day for the duration of the experiment, ranging from 26 to 30 days. All dead fish were sampled, transferred immediately to $-80^{\circ} \mathrm{C}$, and stored until processing.

\subsection{Histopathology}

In one experiment, an additional 10 fish of each of the 4 species/stocks ( 3 week-old rainbow trout, 2.5 month-old steelhead trout, 5.5 month-old sockeye salmon, and 11month old koi) were challenged with virus by IP injection with $6.5 \times 10^{5} \mathrm{PFU} / \mathrm{ml}$ and placed into single tanks for sampling at various time points to assess virus pathology by histological examination. An identical mock treatment, consisting of an IP injection with cell culture media, was also performed for each species/stock (10 fish/tank). One fish of each test species from both mock and virus treatments was euthanized with an anesthetic overdose of buffered solution of MS-222 on days 9, 15, and 20 post-exposure using the procedures described by Kell et al. (2013) and processed for histological examination. For the positive control fish species, a single koi was sampled from each of the mock and virus time-point tanks on days $3,5,7,9,15,20$, and 25 post-exposure and also processed for histopathology.

Fish for histopathology were injected with sufficient amount of Dietrich's fixative solution (30 mL 95\% ethanol, $10 \mathrm{~mL}$ formalin [Formaldehyde $37 \%$ solution with $10 \%$ to 15\% methanol], $2 \mathrm{~mL}$ glacial acetic acid, and $58 \mathrm{~mL}$ distilled water) to preserve the 
internal organs, and fixed for at least $48 \mathrm{~h}$ before transfer to $70 \%$ ethanol, then processed as described by Sanders et al. (2003). Blind analysis of gills, heart, liver, spleen, skeletal muscle, kidney, testes, ovaries, gastrointestinal tract, pancreas, thymus, spinal cord, vertebra, swim bladder, peritoneum, buccal cavity, and pituitary gland was performed by light microscopy and any tissue aberrations or lesions were noted.

\subsection{Processing of frozen fish samples}

A subset of dead fish and euthanized survivors were assessed for viable virus by plaque assay. Single fish were thawed and initially diluted in a volume of minimum essential medium containing Fungizone ${ }^{\circledR}$ (Life Technologies), penicillin, and gentamicin, and homogenized with a Stomacher-80 (Seward Laboratory Systems, Biomaster). The homogenate was then spun down for $10 \mathrm{~min}$ at $1,000 \times \mathrm{g}$. The initial homogenate supernatant was further diluted in the same medium to a 1:40 dilution and infectious virus titers $(\mathrm{PFU} / \mathrm{g})$ for individual fish were determined by plaque assay using procedures cited above.

\subsection{RNA extraction and nested reverse transcription PCR}

In experiments with yellow perch and older $(83 \mathrm{~m})$ koi, a $210-\mu \mathrm{L}$ portion of tissue homogenate supernatant was also processed immediately for RNA extraction following manufacturer's protocols for the Qiagen RNeasy kit (Qiagen, Hilden, Germany). Reagents (Promega, Madison, Wisconsin, USA) for the $1^{\text {st }}$ round of the nested reverse transcription polymerase chain reaction (PCR) included: $5 \mu 1$ each of $25 \mathrm{mM} \mathrm{MgCl}$ and $2.5 \mathrm{mM}$ dNTP mixture, plus $0.5 \mu 1$ each of avian myeloblastosis virus reverse 
transcriptase (AMV RT) and GoTaq DNA polymerase (both from Promega). External primers, previously used by Stone et al. (2003) in a SVCV glycoprotein (G)-gene sequence phylogeny study, consisted of 50 pmol each of the forward R2 primer $\left(5^{\prime}\right.$ AGATGGTATGGACCCCAATACATHACNCAY 3') and reverse primer (5' TCTTGGAGCCAAATAGCTCARRTC $\left.3^{\prime}\right)$. Nuclease free water and $5 \mu$ l of total RNA (10 - $20 \mathrm{ng}$ ) were added to a final volume of $50 \mu \mathrm{l}$ for a single reaction that was run on a PTC- 100 thermocycler (Bio-Rad, Hercules, CA, USA) beginning with a 30 min RT incubation, followed by $2 \mathrm{~min}$ at $95^{\circ} \mathrm{C}$, then cycling parameters of $30 \mathrm{~s}$ at $95^{\circ} \mathrm{C}, 30 \mathrm{~s}$ at $50^{\circ} \mathrm{C}, 1 \mathrm{~min}$ at $72^{\circ} \mathrm{C}$ repeated 29 times, and ending with 7 min at $72{ }^{\circ} \mathrm{C}$ and holding at $4^{\circ} \mathrm{C}$.

Reaction parameters remained the same for the second round "nested" PCR except the AMV RT enzyme and RT incubation period were removed. Also internal SVCV G-gene primers $379+\left(5^{\prime}\right.$ TTTCCCCCTCAAATTGCGG 3') and 825- (5'

CGTTCCATCAGCACATTCAGG 3'), based on conserved G-gene regions delineated by Björklund et al. (1996), were used in the second round PCR (from here on referred to as nested PCR). The nested product was subjected to electrophoresis with reaction products from positive (SVCV cell culture supernatant) and negative (PCR reaction solution without template) controls. Samples producing bands at the anticipated size (447 base pairs) were considered positive for SVCV.

\subsection{Data Analyses}

Mortality challenge data were statistically analyzed using GraphPad InStat Version 3.1a software. Cumulative percent mortality (CPM) values from duplicate treatment 
tanks for the salmonid and fathead minnow virus challenges were statistically evaluated with a Fisher's exact test. CPM from the triplicate treatment tanks of the yellow perch challenges were arcsine transformed prior to statistical assessment by a 1-way analysis of variance (ANOVA) and a Tukey-Kramer multiple comparison post-test if applicable to compare CPM between treatments. A significant relationship was designated for comparisons yielding $\mathrm{p}$ values of $\leq 0.05$. Statistical significance between the virusexposed test species and its matching negative (mock) control is delineated by an asterisk adjacent to the test species name on the mortality graph figures.

\section{Results}

\subsection{Mortality}

Cumulative percent mortality (CPM) for the negative (mock) control groups of all species was negligible, all less than or equal to 10\% CPM (Figures 1, 2, and 3). All mock treated fish tested for virus were negative by plaque assay and nested PCR (data not shown). Table 1 summarizes the fish age and body weight, exposure method, and mean CPM of each species tested for all SVCV challenge experiments performed in this study. Mortality graphs displaying the kinetics of mortality and mean CPM for the salmonids (Figure 1), yellow perch (Figure 2), and fathead minnows (Figure 3) are presented. Many of the dying fish demonstrated clear clinical signs of disease, such as coelomic distension, exopthalmia, and hemorrhaging in various locations on the external body surface (Fig. 4). Clinical signs were exhibited in at least some fish for every fish species tested. 


\subsubsection{Salmonid Mortality and Pathology}

Sockeye salmon fry at 1.5 months of age all died after virus injection, thus experiencing the equivalent mortality $(100 \% \mathrm{CPM})$ as the 5 -month old koi injected with SVCV in the same challenge (Figure 1 Panel B). However, sockeye fry exposed by injection and immersion at 5.5 months of age were relatively resistant to infection with mortalities less than 5\% CPM (Figure 1 Panel C). The dead sockeye at 1.5 months of age that were tested $(\mathrm{n}=6)$ for virus were all positive with a mean titer of $9.4 \times 10^{6} \mathrm{PFU} / \mathrm{g}$ (Figure 5). The single sockeye at 5.5 months of age that died 10 days after injection of virus had a titer of $3.55 \times 10^{6} \mathrm{PFU} / \mathrm{g}$, which was approximately a log higher than the inoculum dose. No virus was detected in any of sockeye survivors tested by plaque assay (Figure 5). Additionally two virus-exposed 5.5 month-old sockeye that were in a tank designated for histology sampling died on days 14 and 24 post-exposure and were instead screened for virus by plaque assay, revealing positive titers of $1.0 \mathrm{X} 10^{7} \mathrm{PFU} / \mathrm{g}$ and $1.0 \mathrm{X}$ $10^{4} \mathrm{PFU} / \mathrm{g}$ respectively. The 5.5 month-old sockeye sampled on days 9,15 , and 20 postvirus exposure that were evaluated histologically, exhibited congested blood vessels in the gills, kidney, pancreas, and peritoneum $(n=3 / 3)$ as compared to the mock treated sockeye.

The highest mortalities for rainbow trout, $40 \%$ and $15 \%$ by injection and immersion respectively, occurred at 1.5 months of age (Figure 1 Panel A), whereas groups of virusexposed rainbow trout exposed by immersion at 3-weeks or by injection at 2.5 months of age each suffered only 5\% mortality (Figure 1 Panels B and C). Steelhead trout, also at 2.5 months of age, experienced a similarly low mortality of $10 \%$ after virus injection (Figure 1 Panel C). The majority of rainbow and steelhead trout that died during 
challenge tested positive for virus $(n=10 / 11)$ with the lowest titer of $1.5 \times 10^{2} \mathrm{PFU} / \mathrm{g}$ from a fish that died on day 3 post-exposure and the highest titer $\left(1.0 \times 10^{7} \mathrm{PFU} / \mathrm{g}\right)$ in a fish that died on day 16 (Fig. 5).

Histological assessment of virus-exposed rainbow trout displayed congested blood vessels in the gills, kidney, pancreas, and peritoneum when sampled at every time point $(\mathrm{n}=3 / 3$; days $9,15,20)$ after injection challenge at 3 weeks of age as compared to slide sections from the mock treated fish. However, for virus-treated $2.5 \mathrm{~m}$ old steelhead trout, only the fish sampled on day 20 post-exposure with mild renal tubular necrosis $(n=1 / 4)$ showed any disease signs by histological examination. Only mild histological lesions were found in the rainbow trout, steelhead trout, and older $(5.5 \mathrm{~m})$ sockeye salmon after SVCV exposure, which correlated well with the low CPM rates observed in these groups of salmonids.

The single Chinook salmon that succumbed to virus 18 days after injection (5\% CPM, Figure 1 Panel B) had a titer of $2.7 \times 10^{6} \mathrm{PFU} / \mathrm{g}$. Virus prevalence was low among the SVCV-exposed salmonid survivors tested $(n=3 / 27)$ with virus only being detected in Chinook and steelhead trout with mean titers ranging from $2.05 \times 10^{3}$ to $2.12 \times 10^{5}$ PFU/g (Fig. 5).

\subsubsection{Yellow perch mortality and infection}

Older yellow perch at 15 to 15.5 months of age had very few deaths (average 4 - 7\%) after SVCV exposure by injection or immersion (Fig. 2 Panel A). Moderate mortality (33\%) did occur with 3 -month old perch injected with virus, but only $2 \%$ mortality occurred in this same age cohort by immersion (Fig. 2 Panel B). Virus detection by 
plaque assay in older perch that died after injection with virus was low $(n=1 / 4)$ as compared to older perch exposed by immersion ( $n=5 / 6$, Fig. 6$)$. However, the single positive dead older perch had a much higher titer $\left(2.38 \times 10^{7} \mathrm{PFU} / \mathrm{g}\right)$, than the mean concentration $\left(2.63 \times 10^{5} \mathrm{PFU} / \mathrm{g}\right)$ of virus found in the older perch that died after immersion challenge. Virus was detected by nested PCR testing in most of the dead and surviving younger and older perch that were injected with virus (Fig. 6). Yellow perch that survived virus exposure by immersion all tested negative for virus both by plaque assay and PCR with the exception of one 3-month old perch $(n=1 / 6)$ testing positive by PCR screening (Fig. 6).

\subsubsection{Cyprinid (fathead minnow and koi) mortality and pathology}

Fathead minnows tested by injection at 6 months of age had a maximum mean CPM of $29 \%$ (Table 1). The experiment was extended past the typical 28-day challenge model to 37 days, since fathead minnows were still dying on days $27,28,29$, and 30 postexposure (Figure 3). All 15 dead fish that had been exposed to SVCV were positive for virus with high titers of $1.8 \times 10^{6}$ to $1.5 \times 10^{7} \mathrm{PFU} / \mathrm{g}$. For survivors, virus was detected in $3 / 8$ fathead minnows tested with concentrations ranging from $2.05 \times 10^{3}$ to $3.25 \times 10^{6}$ $\mathrm{PFU} / \mathrm{g}$.

Koi, serving as the susceptible positive control fish species, were challenged simultaneously during nearly all susceptibility tests of salmonids, percids, and fathead minnows. Koi exposed to SVCV by immersion or injection from 2.5 to 18 months of age had mortalities ranging from $70-75 \%$ and $90-100 \%$ respectively (Table 1, Figures 1, 2, and 3). No mortality curve is presented for koi challenged at 3.5 months of age since they 
were tested alone, with no other fish species, in order to generate negative and positive control tissues for future diagnostic assays. A tested subsample $(n=37)$ of $2.5-18$ months old koi that died after injection or immersion challenge with SVCV were all positive for virus by plaque assay with geometric mean virus concentrations of between $5.09 \times 10^{6}$ to $5.0 \times 10^{7} \mathrm{PFU} / \mathrm{g}$. The few younger $(2.5-18 \mathrm{~m})$ koi that survived to be tested $(n=11)$ at the end of each challenge experiment (26 - 37 days post-exposure) were also all virus-positive, but with generally lower titers ranging from $4.8 \times 10^{4}$ to $5.0 \times 10^{7}$ PFU/g. No histological abnormalities were observed in the single virus-exposed 11month old koi that was euthanized on day 3 post-exposure to SVCV. Histological lesions were observed in the liver and gastrointestinal tract of the dead 11-month old koi sampled on days 5,7 , and 9 post-infection $(n=3)$, however confirmation of true necrosis was confounded due to the rapid rate of post-mortem tissue autolysis. No koi were available for sampling after day 9 since they all had succumbed to SVC disease.

The 83-month old koi subjected to virus by immersion experienced only $11 \% \mathrm{CPM}$ (Figure 2 Panel A). However, all dead $(n=6)$ or surviving $(n=7) 83$-month old koi screened for virus were positive both by nested PCR and plaque assay, with mean titers of $1.3 \times 10^{7} \mathrm{PFU} / \mathrm{g}$ and $1.7 \mathrm{X} 10^{5} \mathrm{PFU} / \mathrm{g}$ for dead and surviving fish respectively (Fig. 6).

\section{Discussion}

\subsection{Salmonids}

Overall this study suggests that salmonid fish species do not appear to a have an intrinsic predisposition to SVCV infection and disease. Of the species tested, sockeye salmon may carry the highest risk of virus host adaptation based on the severity of 
mortality seen in very young fry. Rainbow trout, steelhead trout, and Chinook salmon were not highly vulnerable to SVC disease. Haenen and Davidse (1993) also saw no pathogenicity in rainbow trout fry exposed to SVCV by immersion challenge.

\subsection{Percids}

Rhabdoviruses infect a variety of fish species from the family Percidae. Viruses isolated from pike-perch Stizostedion lucioperca and European perch Perca fluviatilis, were initially suggested to be SVCV (Dorson et al., 1984; Vicenova et al., 2011). However, further characterization of these isolates by Betts and colleagues (2003), and recent comprehensive phylogenetic analyses (Talbi et al., 2011; Stone et al., 2013) of fish rhabdoviruses indicate that these previously suspect SVCV isolates are perch rhabdovirus (PRV) viruses, members of the Perhabdovirus genus, or closely related variants. Both viral hemorrhagic septicemia virus (VHSV) and infectious hematopoietic necrosis virus (IHNV) of the Novirhabdovirus genus are also able to infect yellow perch. Various VHSV genotypes caused moderate to high mortality in yellow perch via in laboratory challenges (Kim and Faisal, 2010; Emmenegger et al., 2013) and natural epidemics due to genotype VHSV-IVb in yellow perch populations from the Great Lakes watershed have occurred (Kane-Sutton et al., 2010; Getchell et al., 2014). For IHNV, which is primarily a salmonid virus, natural infection of yellow perch has not been reported, but experimental exposure by injection challenge did result in infection with low mortalities, with high virus titers in survivors 28 days post-exposure (Palmer and Emmenegger, 2014). Our study establishes that SVCV, a rhabdovirus of the Sprivivirus genus, can also infect yellow perch, induce moderate mortality in fry, and persist in survivors of injection challenge for 28 days. 


\subsection{Cyprinids}

As expected, koi experienced high and consistent mortality to SVCV, both by injection and immersion up to 11 months of age. Koi older than a year may only be vulnerable to disease under experimental conditions when injected with virus. In a previous study, common carp demonstrated decreased susceptibility to a European SVCV strain after 12 months of age during experimental challenges by bath and co-habitation, but were susceptible to infection by injection (Veselý et al., 2014). Likewise an "age related increase of fish resistance to the virus" was seen in common carp and grass carp following injection exposure (Shchelkunov and Shchelkunova 1989). Though older infected koi have lower mortality, our study along with other previous reports demonstrated that koi and carp survivors regardless of age can harbor SVCV for long periods and most likely shed the virus (Wolf, 1988; Ahne et al., 2002; Emmenegger and Kurath, 2008).

A moderate level of susceptibility to SVCV was seen in the other cyprinid species we tested by injection with a final CPM well below that observed in koi of comparable age. The slow chronic nature of the fathead minnow mortalities and the persistence of the virus in the survivors may indicate that fathead minnows could also be potential carriers of the virus.

\subsection{Factors influencing host susceptibility}

It is well known that host age, broodstock, challenge method, virus strain, water temperature, and rearing conditions influence infection outcomes. Therefore accurate 
assessments of susceptibility to pathogens under laboratory conditions are complicated. For example, injection as the route of virus exposure may overestimate species vulnerability, whereas testing species at a single water temperature or by immersion alone may underestimate the species level of susceptibility.

\subsubsection{Age, broodstock, and virus strain}

Our SVCV challenges suggested that host age is a key factor, in association with the inherent level of species susceptibility, in determining the risk of infection and disease. Younger age classes for all species tested were more vulnerable, which is typical for SVCV infections (Wolf, 1988; Shchelkunov and Shchelkunova, 1989; Ahne et al., 2002). For sockeye, the age of greatest risk appears to be 1.5 months of age and weight of $\leq 1.0$ g. At this size, the salmonid immune system is still developing, which limits their ability to fight infection (Ellis, 1988). Our findings may indicate that there is a narrow window of age-related vulnerability for disease progression (i.e. death) in a semi-resistant host species.

Older salmonids were more resistant to disease, however those that did die had moderate to high levels of virus. Among older sockeye survivors, no virus was detected by plaque assay and no significant histological abnormalities were noted indicating that older sockeye may either be resistant to infection entirely or can rapidly clear the virus after initial infection. Steelhead trout and Chinook salmon were the only salmonids for which survivors had detectable levels of virus. Further co-habitation studies with a susceptible recipient species would be needed to determine if salmonid survivors were shedding transmissible virus. 
Yellow perch and fathead minnows at 3 and 6 months of age, respectively, both experienced moderate mortalities in our experimental challenges. However if the fathead minnows and yellow perch had been younger, the mortalities might have been higher and more acute. Performing challenges at intervals during rearing would clarify the age of highest susceptibility.

In addition to the effect of age, testing different broodstocks of each species would better define a fish species level of susceptibility. For example, yellow perch of three different broodstocks had significant variation in mortality when challenged with VHSVIVb (Olson et al., 2013). Similarly, using multiple virus strains/genotypes would better demonstrate if a fish species has broad susceptibility or constricted strain-specificity to a particular pathogen as shown for VHSV (Emmenegger et al., 2013) and IHNV (LaPatra et al., 1993; Garver et al., 2006; Breyta et al., 2013).

For SVCV, goldfish are a good example of the difficulties associated with the estimation of host species susceptibility to a virus by experimental exposures. As a cyprinid species with numerous reports of SVCV isolations (Stone et al. 2003, Miller et al. 2005), it is logical to assume that goldfish would suffer sizable fatalities when experimentally challenged. However, some studies indicated that they were refractory or resistant to SVC (Ahne 1973; Kanellos et al. 2006; Emmenegger and Kurath 2008), while other studies reported substantial mortalities (Alexanderino et al. 1998; Goodwin 2002) illustrating that disease outcomes are heavily dependent on the experimental parameters employed in testing fish for susceptibility to pathogens in a laboratory setting. 


\subsubsection{Temperature}

Initial infection of the host and subsequent expression of disease is highly temperature dependent for SVCV in both experimental and natural settings (Ahne et al., 2002). In our experiment, sockeye fry seemed particularly vulnerable to the variable water temperature regime used in our challenge (e.g. $9-10^{\circ} \mathrm{C}$ at start of challenge then increased to $13-14^{\circ} \mathrm{C}$ ). Sockeye salmon inhabit the waters of Alaska south to the Columbia River of the Pacific Ocean and are highly susceptibility to IHNV with epidemics being reported in both wild and hatchery fish (Amend et al., 1969; Bootland and Leong, 2011). IHNV is thought to have originated in Alaskan stocks of sockeye and adapted to other salmonid species, such as rainbow trout, and perhaps Chinook salmon, in watersheds with warmer water temperatures along lower NE Pacific coast (Amend, 1975; Kurath et al., 2003). IHNV is a pathogen of coldwater fish species, like salmonids, while SVCV typically infects temperate or warm water fish species (Fijan, 1999). If salmonids begin to acclimate to warmer waters and start to encounter aquatic species carrying SVCV the risk of crossspecies transmission may be highest for sockeye salmon.

Significant water temperature variations along the Pacific coast and inland water systems have recently been documented, along with sightings and capture of aquatic species outside of their typical range (Doney et al., 2012; Okey et al., 2014; Roemmich et al., 2015). Eaton and Scheller (1996) performed a thermal analysis of how climate change would affect the habitat range of 57 freshwater fish species and predicted that coldwater species could have a 50\% reduction in habitat and that some warm water species spatial ranges would expand. The fish species with the highest percent potential habitat increase due to climate change were bluegill and largemouth bass, which are the 
newest fish species to be associated with the latest outbreaks of SVCV in the U.S. (Phelps et al., 2012). Climate perturbations resulting in non-native species incursions (Kulhanek et al., 2011) or invasive species introductions in conjunction with other key risk factors may present an environment suitable for novel pathogen host jumps in the future. Testing naive host species with a range of stable and fluctuating water temperatures would aid in determining the temperature profiles at which fish species are the most vulnerable to exotic pathogen transmissions.

\subsubsection{Rearing conditions}

Absence of disease in the rainbow trout we tested under experimental conditions is interesting, since previous SVCV isolations from salmonids were reported only in rainbow trout (Stone et al., 2003; Shchelkunov et al., 2005; Jeremić et al. 2006; Asl et al. 2008b). Outbreaks with high losses have even occurred in older (1 yr old) farm-raised rainbow trout during spring and summer months (Jeremić et al., 2006; Asl et al., 2008b). These fish were pond-reared, suggesting that static water and other aquaculture rearing conditions along with rising water temperatures were sufficient co-stressors to override a mature host immune system in a species inherently resistant to SVC disease. It has also been stated that rainbow trout fry were infected and suffered mortalities when reared in the same facility with common carp recovering from SVCV infection (Shchelkunov et al., 2005). These incidences suggest that cyprinids have the potential to spread virus to more SVCV-resistant fish species, especially if exposure to cyprinids is prolonged, such as in poly-aquaculture settings.

Similarly the moderate mortalities seen in fathead minnows suggests that in some cases laboratory challenge conditions (e.g. filtered flow-thru water, stable temperatures, 
immediate removal of moribund or dead fish) are unable to sufficiently mimic the stress parameters found in nature, or in hatcheries/farms, that can induce disease progression in semi-susceptible species. In nature, lower water quality in part due to anthropogenic factors (landscape alterations [dams, bridges], pollution, etc.) compounded with thermal stress are sustained for long periods, which eventually can initiate a disease cascade. Aquaculture rearing conditions stressful to the host, such as overcrowding, high feed rates, and water-fouling, may also be able to shift a low-grade infection in fish species that is semi-vulnerable to SVCV to a more diseased state.

\subsection{Summary and conclusions}

In summary, our experimental challenges reiterated the trend that fish of younger age classes were more vulnerable to SVCV infection than older fish and that in some species there may be a narrow age-related time frame for virus transmission. We determined that yellow perch and fathead minnows exposed by injection can be infected with SVCV and suffer moderate mortalities. The most unusual finding was that sockeye salmon fry after virus injection could experience the same high level of mortality as the primary SVCV host species (koi).

Practices related to fish stocking, aquaculture, and the aquarium industry are described as the primary portals for the invasion of non-native fish species (Bobeldyk et al., 2015). Fish remain one of the most traded food commodities worldwide with salmon and trout being the second most traded aquatic species just after shrimp (14\% versus $15 \%$ respectively; FAO, 2014), and non-native rainbow trout are considered the world's most widely introduced invasive fish species (Halverson, 2010). Ornamental fish are also 
traded internationally and reared globally for the aquarium industry, with koi and goldfish being among the top multinational traded fish species (Cheong, 1996). Common carp are valued worldwide as a food resource, recreational game species, and aquaculture product, but are also considered one of the most highly invasive aquatic species when introduced (Lowe et al., 2004, Shelton and Rothbard, 2006; Santella, 2012). Cyprinids, with their inherent SVCV susceptibility and ability to act as carriers, may serve as a conduit species for SVCV transmission to native North American fish populations. The Pacific Northwest region with its moderate temperature regimes and ongoing climatic shifts is a region in which introduced aquatic species can survive and become established (Dukes and Mooney, 1999; Strecker et al., 2011). Concomitantly the viability and dissemination of hitchhiker pathogens, like SVCV, to at-risk fish populations is also probable, especially when host and environmental factors are conducive for virus transmission.

\section{Acknowledgments}

Many thanks to Andy Goodwin of US Fish \& Wildlife Service for providing fathead minnows and the NC SVCV isolate. Joel Burkhard of Pan Inter Corp. for his generosity in giving us so many koi that we could perform multiple SVCV challenges. Wendy Olson of US Fish \& Wildlife Service and Rick Goetz of NOAA for supplying us with the older yellow perch. Maureen Purcell of the WFRC for letting us have some of her Chinook salmon. Scott LaPatra of Clear Springs Inc. for supporting our research endeavors and in particular for making available his rainbow trout for testing. Thanks to Joan Thomas of the Washington Dept. of Fish \& Wildlife for her assistance in procuring the Cedar River sockeye for this experiment. Bill Batts for sharing his vast technical 
knowledge. This research was funded in part by the USGS-USFWS Science Support Partnership Program and by the US Geological Survey. Any use of trade, firm, or product names is for descriptive purposes only and does not imply endorsement by the U.S.

Government.

\section{Declaration of conflicting interests}

The author(s) declared no potential conflicts of interest with respect to the research, authorship, and/or publication of this article.

\section{References}

Ahne, W., 1973. Zellkulturen aus verschiedenen Süsswasser-teleosteergeweben und Untersuchungen über die Ätiologie der Schwimmblasenentzündung der Karpfen. PhD thesis, Ludwig-Maximilians Universität, Munich

Ahne, W., 1985. Viral infection cycles in pike (Esox lucius L.). J. Appl. Ichthyol. 1, 9095.

Ahne, W., Kurath, G., Winton, J.R., 1998. A ribonuclease protection assay can distinguish spring viremia of carp virus from pike fry rhabdovirus. Bulletin Euro. Assoc. Fish Pathologits. 18, 220-224.

Ahne, W., Bjorklund, H.V., Essbauer, S., Fijan, N., Kurath, G., Winton, J.R., 2002. Spring viremia of carp (SVC). Dis. Aquat. Organ; 52, 261-272.

Alexandrino, A.C., Ranzani-Paiva, M.J.T., Romano, L.A., 1998. Identificación de viremia primaveral de la carpa (VPC) Carrassius auratus en San Pablo, Brasil. Revista Ceres, 45, 125-137.

Amend, D.F., Yasutake, W.T., Mead, R.W., 1969. A hematopoietic virus disease of rainbow trout and sockeye salmon. Trans. Amer. Fisheries Soc. 98, 796-804.

Amend, D.F., 1975. Detection and transmission of infectious hematopoietic necrosis virus in rainbow trout. J. Wild. Dis. 11, 471-478.

Ariel, E., 2005. Ornamental fish as trans-boundary vectors of viral diseases. In P. Walker, R. Lester and M.G. Bondad-Reantaso (eds). Diseases in Asian Aquaculture V, pp. 103112. Fish Health Section, Asian Fisheries Society, Manila.

Asl, A.H.K., Azizzadeh, M., Bandehpour, M., Sharifnia, Z., Kazemi, B., 2008a. The first report of SVC from Indian carp species by PCR and histopathologic methods in Iran. 
Pakistan J. Biological Sci. 11, 2675-2678.

Asl, A.H.K., Bandehpour, M., Sharifnia, Z., Kazemi, B., 2008b. The first report of pring viraemia of carp in some rainbow trout propagation and breeding by pathology and molecular techniques in Iran. Asian J. Anim. Vet. Adv. 3, 263-268.

Bachmann, P.A., Ahne ,W., 1974. Biological properties and identification of the agent causing swim bladder inflammation in carp. Archiv fur die Gesamte Virusforschung, 44, 261-269.

Batts, W.N., Winton, J.R., 1989. Enhanced detection of infectious hematopoietic necrosis virus and other viruses by pretreatment of cell monolayers with polyethylene glycol. J. Aquat. Anim. Health 1, 284-290.

Betts, A.M., Stone, D.M., Way, K., Torhy, C., Chilmonczyk, S., Benmansour, A., DeKinkelin, P., 2003. Emerging vesiculo-type virus infections of freshwater fishes in Europe. Dis. Aquat. Org. 57, 201-212.

Björklund, H.V., Higman, K.H., Kurath, G. 1996. The glycoprotein genes and gene junctions of the fish rhabdoviruses spring viremia of carp and hirame rhabdovirus: analysis of relationships with other rhabdoviruses. Virus Res. 42, 65-80.

Bobeldyk, A.M., Rüegg, J., Lamberti, G.A., 2015. Freshwater hotspots of biological invasion are a function of species-pathway interactions. Hydrobiologia 746, 363-373.

Bootland, L.M., Leong, J.A.C., 2011. Infectious haematopoietic necrosis virus. Pages 66109 in P.T.K. Woo, J.F. Leatherland, and D.W. Bruno, editors. Fish diseases and disorders, volume 3: viral, bacterial, and fungal infections, $2^{\text {nd }}$ Edition. CAB International, London.

Breyta, R., Jones, A., Stewart, B., Brunson, R., Thomas, J., Kerwin, J., Bertolini, J., Mumford, S. Patterson C., Kurath, G., 2013. Emergence of MD type infectious hematopoietic necrosis virus in Washington State coastal steelhead trout. Dis. Aquat. Org. 104, 179-195.

Cheong, L., 1996. Overview of the current international trade in ornamental fish, with special reference to Singapore. Revue scientifique et technique (International Office of Epizootics). 15, 445-481.

Dikkeboom, A. L., Radi, C., Toohey-Kurth, K., Marcquenski, S., Engel, M., Goodwin, A. E., Way, K., Stone, D.M., Longshaw, C., 2004. First report of spring viremia of carp virus (SVCV) in wild common carp in North America. J. Aquat. Anim. Health 16, 169178.

Dixon P., Hattenberger-Baudouy A., Way K., 1994. Detection of carp antibodies to spring viraemia of carp virus by a competitive immunoassay. Dis Aquat. Org. 19, 181-6. 
Doney, S.C., Ruckelshaus, M., Emmett Duffy, J., Barry, J.P., Chan, F., English, C.A., Galindo, H.M, Grebmeier, J.M., Hollowed, A.B., Knowlton, N., Polovina, J., Rabalais, N.N., Sydeman, W.J., Talley, L.D., 2012. Climate change impacts on marine ecosystems. Ann. Rev. Mar. Sci., 4, 11-37.

Dorson, M., Torchy, C., Chilmonczyk, S., Kinkelin, P. D., Michel, C., 1984. A rhabdovirus pathogenic for perch, Perca fluviatilis L.: isolation and preliminary study. J. Fish Dis. 7, 241-245.

Dukes, J.S., Mooney, H.A., 1999. Does global change increase the success of biological invaders? Trends Ecol. Evol. 14, 135-139.

Eaton, J.G., Scheller, R.M, 1996. Effects of climate warming on fish thermal habitat in streams of the United States. Limnolog. Oceanogr. 41, 1109-1115.

Ellis, A.E., 1988. Ontogeny of the immune system in teleost fish. In Fish vaccination. Ellis A.E., (ed.). London, UK: Academic Press, pp. 20-31.

Emmenegger, E.J., Kurath, G., 2008. DNA vaccine protects ornamental koi (Cyprinus carpio koi) against North American spring viremia of carp virus. Vaccine, 26, 6415-6421.

Emmenegger, E.J., Moon, C.H., Hershberger, P.K., Kurath, G., 2013. Virulence of viral hemorrhagic septicemia virus (VHSV) genotypes Ia, IVa, IVb, IVc, in five fish species. Dis. Aquat. Org. 107, 99-111.

FAO, 2014. Food and Agriculture Organization of the United Nations. The State of World Fisheries and Aquaculture. Rome, FAO. 243 pp.

Fijan, N.N, Petrinec Z., Sulimanovic D., Zwillenberg, L.O., 1971. Isolation of viral causative agent from the acute form of infectious dropsy in carp. Veterinari Arhiv (Zagreb) 41, 125-138.

Fijan, N., Sulimanovic, D., Bearzotti, M., Muzinic, D., Zwillenberg, L.O., Chilmonczyk, S., Vautherot, J.F., de Kinkelin, P., 1983. Some properties of the epithelima papulosum cyprinid (EPC) cell line from carp Cyprinus carpio. Ann Instit Pasteur Virol 134:207220.

Fijan, N., Matasin, Z., Jeney, Z., Olah, J., Zwillenberg, L.0., 1984. Isolation of rhabdovirus carpio from sheatfish (Silurus glanis) fry. Symp. Biol. Hung. 23, 17-24.

Fijan, N., 1999. Spring viraemia of carp and other viral diseases and agents of warm water fish. Pages 177- 244 in P. T. K. Woo and D. W. Bruno, editors. Fish diseases and disorders, volume 3: viral, bacterial, and fungal infections. CAB International, London. 
Gado, M.S.M., Saad, T.T., El-Dein, A.A., 2015. Primary isolation and characterization of spring viremia of carp virus (SVCV) from cultured fish in Kafer El-Shikh Governorate.

Am. J. Life. Sci. Res. 3, 128-139.

Garver, K.A., Batts, W.N., Kurath, G., 2006. Virulence comparisons of infectious hematopoietic necrosis virus $\mathrm{U}$ and $\mathrm{M}$ genogroups in sockeye salmon and rainbow trout. J. Aquat. Anim. Health, 18, 232-243.

Garver, K.A., Dwilow, A.G., Richard, J., Booth, T.F., Beniac, D.R., Souter, B.W., 2007. First detection and confirmation of spring viraemia of carp virus in common carp, Cyprinus carpio L., from Hamilton Harbour, Lake Ontario, Canada. J. Fish Dis., 30, 665671.

Getchell, R.G., Cornwell, E.R., Bowser, P.R., 2014. Recurrence of VHS outbreaks in the Lower Great Lakes. In Proceedings, 7th International Symposium on Aquatic Animal Health: August 31 - September 4, 2014, Portland, Oregon USA.

Ghasemi, M., Zamani, H., Hosseini, S.M., Haghighi Karsidani, S., Bergmann, S.M., 2014. Caspian white fish (Rutilus frisii kutum) as a host for Spring Viraemia of Carp Virus. Vet. Microbiol. 170, 408-413.

Goodwin, A.E., 2002. First report of spring viremia of carp virus (SVCV) in North America. J. Aquat. Anim. Health, 14, 161-164.

Haenen, O.L.M, Davidse, A., 1993. Comparative pathogenicity of two strains of pike fry rhabdovirus and spring viremia of carp virus for young roach, common carp, grass carp and rainbow trout. Dis. Aquat. Org. 15, 87-92.

Halverson, A., 2010. An Entirely Synthetic Fish: How Rainbow Trout Beguiled America and Overran the World. Yale Univ. Press, New Haven

Jeremić, S., Ivetić, V., Radosavljević, V., 2006. Rhabdovirus carpio as a causative agent of disease in rainbow trout (Oncorhynchus mykiss-Walbaum). Acta veterinaria, 56, 553558.

Johnson, M.C., Maxwell, J.M., Loh, P.C., Leong, J.S., 1999. Molecular characterization of the glycoproteins from two warm water rhabdoviruses: snakehead rhabdovirus (SHRV) and rhabdovirus of penaeid shrimp (RPS)/spring viremia of carp virus (SVCV). Virus Res. 64, 95-106.

Jørgensen, P.E.V, Olesen N.J., Ahne, W., Lorenzen, N., 1989. SVCV and PFR viruses: serological examination of 22 isolates indicates close relationship between the two fish rhabdoviruses. In: Ahne W, Kurstak E (eds) Viruses of lower vertebrates. Springer Verlag, Heidelberg, p349-366.

Kane-Sutton, M., Kinter, B., Dennis, P.M., Koonce, J.F., 2010. Viral hemorrhagic 
septicemia virus infection in yellow perch, Perca flavescens, in Lake Erie. J. Great Lakes Res., 36, 37-43.

Kanellos, T., Sylvester, I.D., D’Mello, F., Howard, C.R., Mackie, A., Dixon, P.F., Chang, K., Ramstad, A., Midtlyng, P.J., Russell, P.H., 2006. DNA vaccination can protect Cyprinus carpio against spring viraemia of carp virus. Vaccine 24, 4927-4933.

Kell, A.M., Wargo, A.R., Kurath, G., 2013. The role of virulence in in vivo superinfection fitness of the vertebrate RNA virus infectious hematopoietic necrosis virus. J. Virol. 87, 8145-8157.

Kim, R.,Faisal, M., 2010. Experimental studies confirm the wide host range of the Great Lakes viral haemorrhagic septicaemia virus genotype IVb. J. Fish Dis. 33, 83-88.

Kölbl, D., 1975. Neue Erkenntnisse über die Bauchwassersucht bei Karpfen. Österr. Fisch. 28, 69-72.

Koutná, M., Veselý, T., Psikal, I., Hůlová, J., 2003. Identification of spring viraemia of carp virus (SVCV) by combined RT-PCR and nested PCR. Dis. Aquat. Org. 55, 229-235.

Kulhanek, S.A., Leung B., Ricciardi, A., 2011. Using ecological niche models to predict the abundance and impact of invasive species: application to the common carp. Ecol. Appl. 21, 203-213.

Kurath, G., Garver, K.A., Troyer, R.M., Emmenegger, E.J., Einer-Jensen, K., Anderson, E.D., 2003. Phylogeography of infectious haematopoietic necrosis virus in North America. J. Gen. Virol. 84, 803-814.

LaPatra, S.E., Fryer, J.L., Rohovec, J.S., 1993. Virulence comparison of different electrophero-types of infectious hematopoietic necrosis virus. Dis. Aquat. Org. 16, 115120.

Liu, H., Fu, F., Huang, J., He, J.Q., Shi, X.J., Gao, L.Y., Yang, J.S., Jiang, Y.L., 2005. Amino acid sequence of a Chinese isolate of spring viraemia virus of carp and preliminary analysis of the glycoprotein gene. Virol. Sinica 20, 647-651.

Lowe, B., Browne, M., Boudjelas, S., De Poorter, M., 2004. 100 of the world's worst invasive alien species. The Invasive Species Specialist Group (ISSG) of the World Conservation Union Auckland, New Zealand.

Marcquenski, S., Dixon, P., LeDeuff, R. M., Sheppard, A., Lasee, B., Marcino, J., 2003. Spring Viremia of carp virus in the Upper Midwest. Proceedings of the 28th Annual Eastern Fish Health Workshop. April 21-25, 2003. Gettysburg, PA. p. 46. 
Miller, O., Fuller, F.J., Gebreyes, W.A., Lewbart, G.A., Shchelkunov, I.S., Shivappa, R.B., Joiner, C., Woolford G., Stone D.M., Dixon P.F., Raley M.E., Levine, J.F., 2007. Phylogenetic analysis of spring viremia of carp virus reveals distinct subgroups with common origins for recent isolates in North America and the UK. Dis. Aquat. Org. 76, 193-204.

National Research Council (NRC), 2011. Guide for the Care and Use of Laboratory Animals: Eighth Edition. National Academies Press Washington (DC): 248 pages.

OIE, 2012. Manual of Diagnostic Tests for Aquatic Animals, Chapter 2.3.8. Spring Viraemia of Carp. $<$ https://www.google.com/\#q=OIE+2012+CHAPTER+2.3.8 >

OIE, 2015. Aquatic Animal Health Code, OIE-Listed diseases, infections and infestations in force in 2015. $<$ http://www.oie.int/en/animal-health-in-the-world/oie-listed-diseases$2015 />$

Okey, T.A., Alidina, H.M., Lo, V., Jessen, S., 2014. Effects of climate change on Canada's Pacific marine ecosystems: a summary of scientific knowledge. Rev. Fish Biol. Fish., 24, 519-559.

Palmer, A.D., Emmenegger, E.J., 2014. Susceptibility of koi and yellow perch to infectious hematopoietic necrosis virus by experimental exposure. J. Aquat. Anim. Health $26,78-83$.

Pasco, L., Torchy, C., de Kinkelin, P., 1987. Experimental infection of sheatfish fry (Silurus glanis L) by spring viremia of carp virus (SVCV). Bull. Fr. Pêche, Piscic. 307, 84-88.

Phelps, N.B., Armién, A.G., Mor, S.K., Goyal, S.M., Warg, J.V., Bhagyam, R., Monahan, T., 2012. Spring viremia of carp virus in Minnehaha Creek, Minnesota. J. Aquat. Anim. Health 24, 232-237.

Roemmich, D., Church, J., Gilson, J., Monselesan, D., Sutton, P., Wijffels, S. 2015. Unabated planetary warming and its ocean structure since 2006. Nature Climate Change. accepted in press

Saad, T., Soad, S.B., Haggag, S.A., 2008. Studies on rhabdovirus affection among carp fishes in Behira Governrate. Suez Canal Vet. Med. J. 1, 207-220.

Sanders, G.E., Batts, W.N., \& Winton, J.R., 2003. Susceptibility of zebrafish (Danio rerio) to a model pathogen, spring viremia of carp virus. Comp. Med. 53, 514-521.

Santella, C., 2012. Carp Gain as a Fly-Fishing Favorite. The New York Times. (February 12, 2012). 
Shchelkunov I.S., Yukhimenko, L.N., Shchelkunova T.I., Trombitsky, I.D., Manchu, A.P., 1984. Isolation of a virus from silver carp with infectious dropsy syndrome.

Fishery employment of inland water reservoirs, CNITEIRCH, Moscow 4, 3-7

Shchelkunov I.S., Shchelkunova T.I., 1989. Rhabdovirus carpio in herbivorous fishes: isolation, pathology and comparative susceptibility of fishes. In: Ahne W., Kurstak E., (eds) Viruses of lower vertebrates. Springer Verlag, Heidelberg, p 333-348

Shchelkunov I.S., Shchelkunova T.I., Oreshkova S.F., Blinova N.N., 2005.

Proceedings of the 32nd Annual Eastern Fish Health Workshop. June 13-17, 2005.

Shepherdstown, WV. p. 53.

Shelton, W.L., Rothbard, S., 2006. Exotic species in global aquaculture-A review. Israeli J. Aquac. 58: 3-28.

Soliman, M.K., Aboeisa, M.M., Mohamed, S.G., Saleh, W.D., 2008. First record of isolation and identification of Spring Viraemia of Carp virus from Oreochromis niloticus in Egypt. In Eighth International Symposium on Tilapia in Aquaculture Proceedings. Cairo, Egypt, 12-14 October, 2008. pp. 1287-1306.

Stone, D.M., Ahne, W., Denham, K.L., Dixon, P.F., Liu, C.T., Sheppard, A.M., Taylor, G.R., Way, K., 2003. Nucleotide sequence analysis of the glycoprotein gene of putative spring viraemia of carp virus and pike fry rhabdovirus isolates reveals four genogroups. Dis. Aquat. Org. 53, 203-210.

Stone, D.M., Kerr, R.C., Hughes, M., Radford, A.D., Darby, A.C., 2013. Characterisation of the genomes of four putative vesiculoviruses: tench rhabdovirus, grass carp rhabdovirus, perch rhabdovirus and eel rhabdovirus European X. Arch. Virol. 158, 23712377.

Strecker, A.L., Campbell, P.M., Olden, J.D., 2011. The aquarium trade as an invasion pathway in the Pacific Northwest. Fish. 36, 74-85.

Talbi, C., Cabon, J., Baud, M., Bourjaily, M., de Boisséson, C., Castric, J., Bigarré, L., 2011. Genetic diversity of perch rhabdoviruses isolates based on the nucleoprotein and glycoprotein genes. Arch. Virol. 156, 2133-2144.

Tompkins, D.M., Carver, S., Jones, M.E., Krkošek, M., Skerratt, L.F., 2015. Emerging infectious diseases of wildlife: a critical perspective. Trends Parasitology. in press (corrected proof posted online)

Veselý, T., Pokorová, D., Reschová, S., Piačková, V., 2014. Experimental infection of common carp (Cyprinus carpio) with spring viremia of carp virus. Proceedings of the Ninth International Symposium on Viruses of Lower Vertebrates, 1-4 October 2014, Malaga, Spain pp. 213-214. 
Vicenova, M., Reschova, S., Pokorova, D., Hulova, J., Vesely, T., 2011. First detection of pike fry-like rhabdovirus in barbel and spring viraemia of carp virus in sturgeon and pike in aquaculture in the Czech Republic. Dis. Aquat. Org. 95, 87-95.

Warg, J.V., Dikkeboom, A.L., Goodwin, A.E., Snekvik, K., Whitney, J., 2007. Comparison of multiple genes of spring viremia of carp viruses isolated in the United States. Virus Genes 35, 87-95.

Winton, J., Batts, W., de Kinkelin, P., LeBerre, M., Bremont, M., Fijan, N., 2010.

Current lineages of the epithelioma papulosum cyprini (EPC) cell line are contaminated with fathead minnow, Pimephales promelas, cells. J. Fish Dis. 33, 701-704.

Wolf, K., 1988. Fish viruses and fish viral diseases. Cornell University Press, Ithaca, NY

Zamani, H., Ghasemi, M., Hosseini, S.M., Karsidani, S.H., 2014. Experimental susceptibility of Caspian white fish, Rutilus frisii kutum to spring viraemia of carp virus. Indian J. Virol. 25, 57-62. 


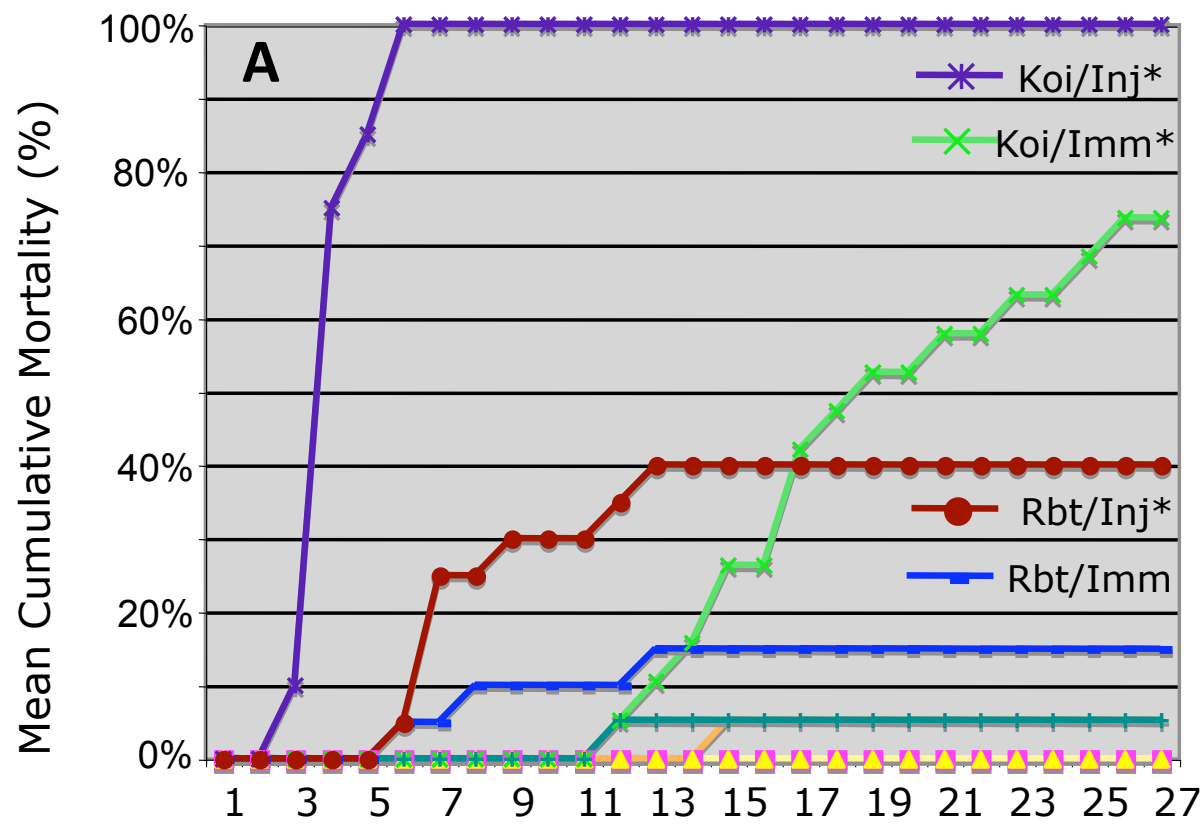

Fig. 1
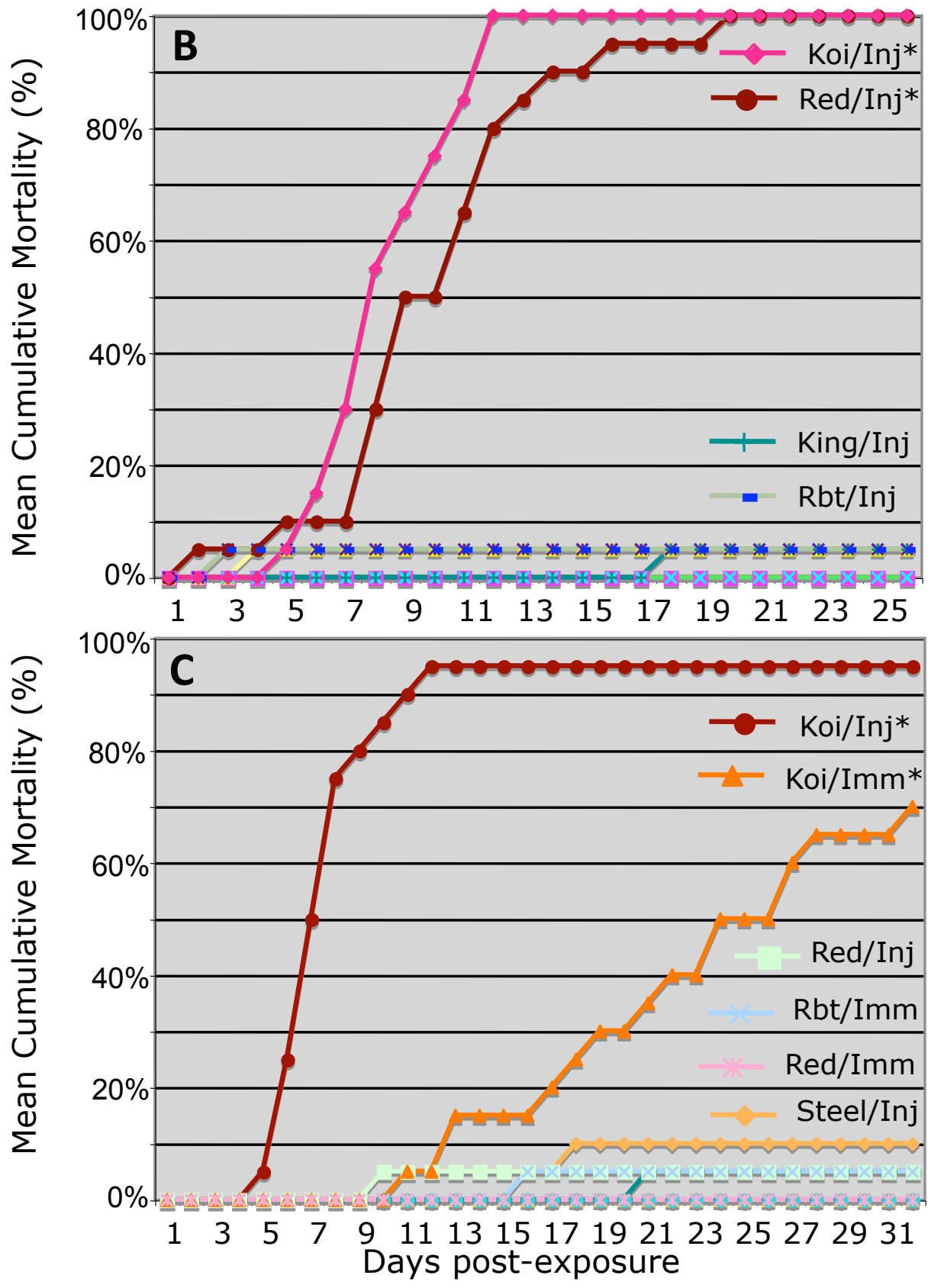
Fig. 2
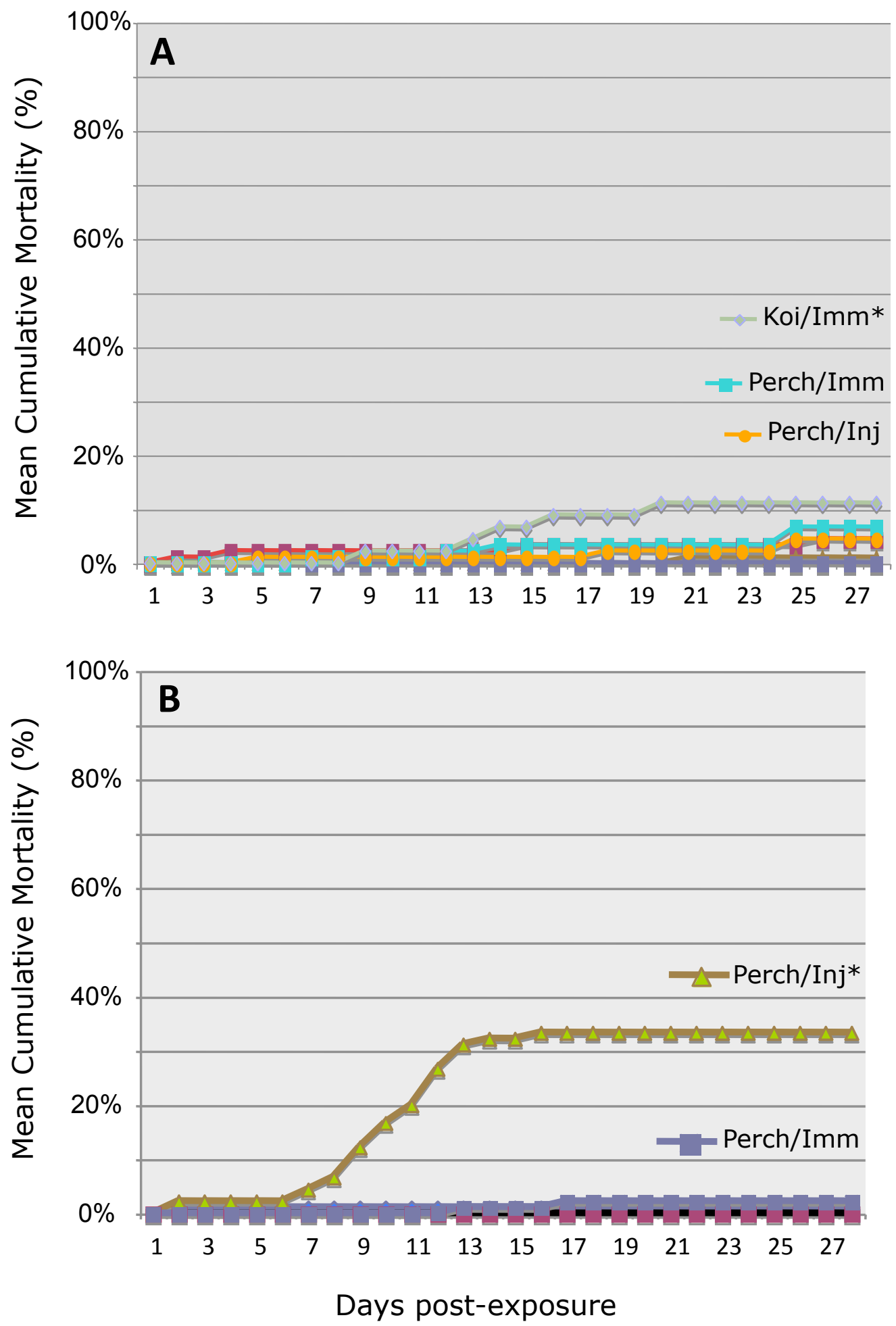
Fig. 3

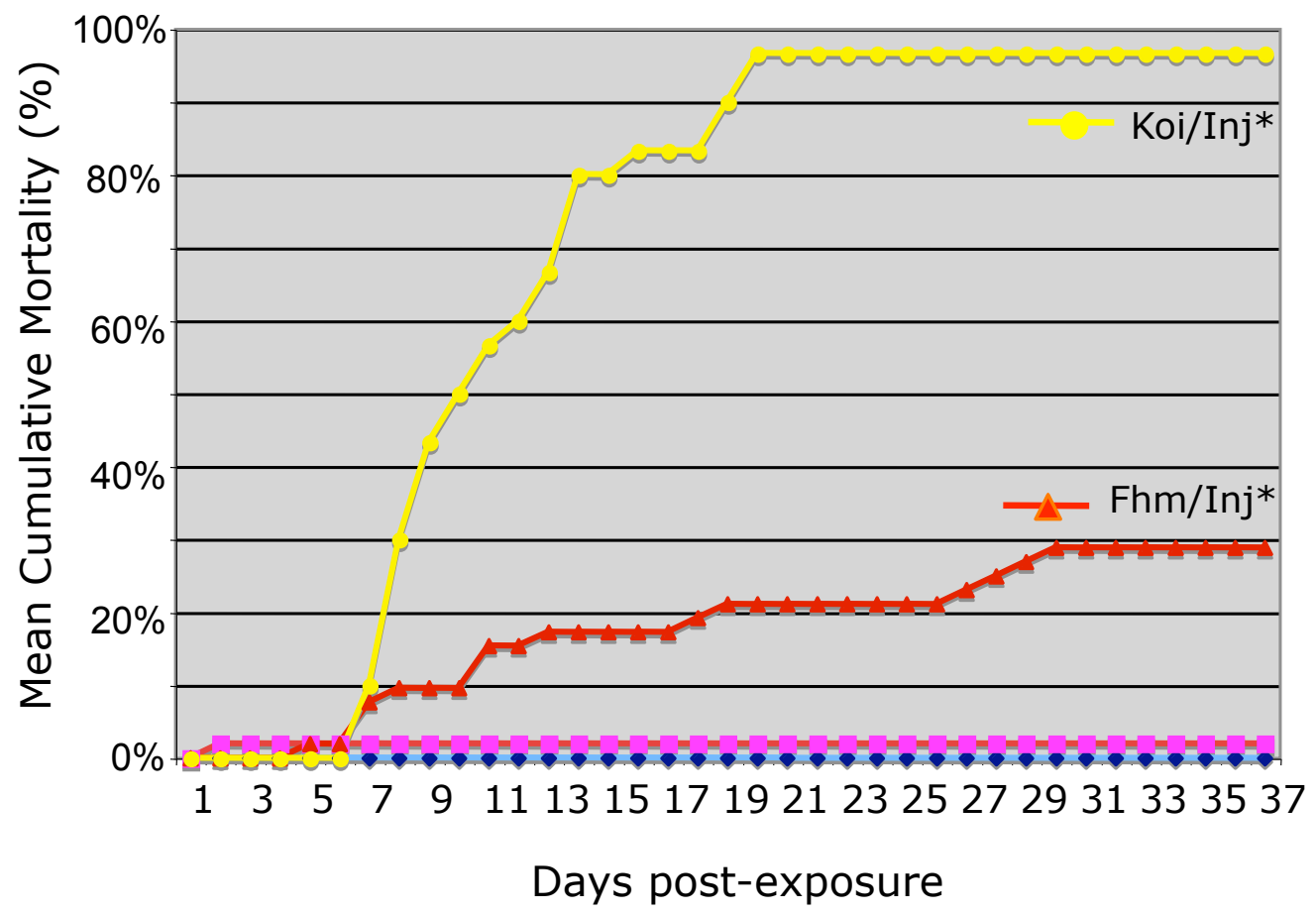




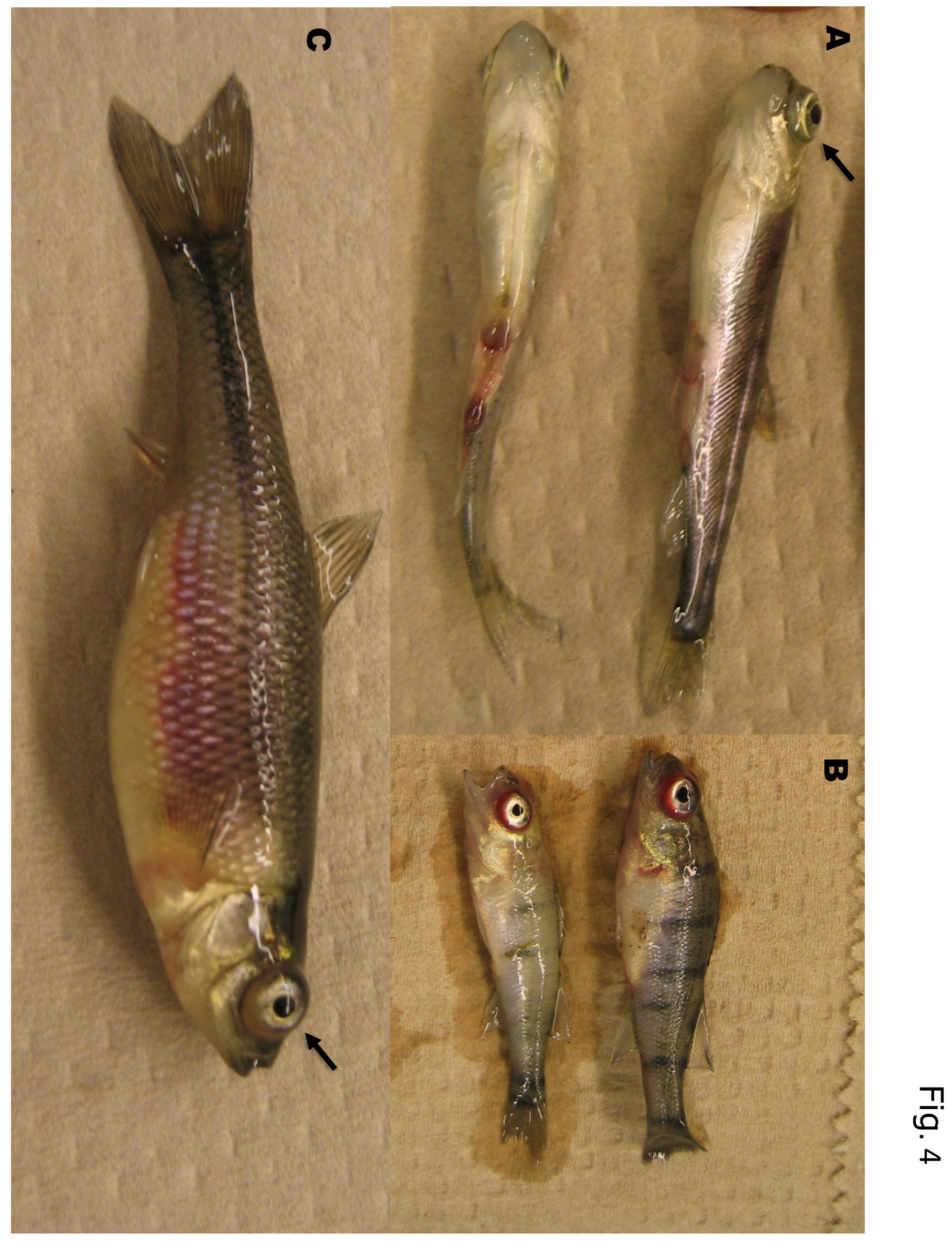


Fig. 5
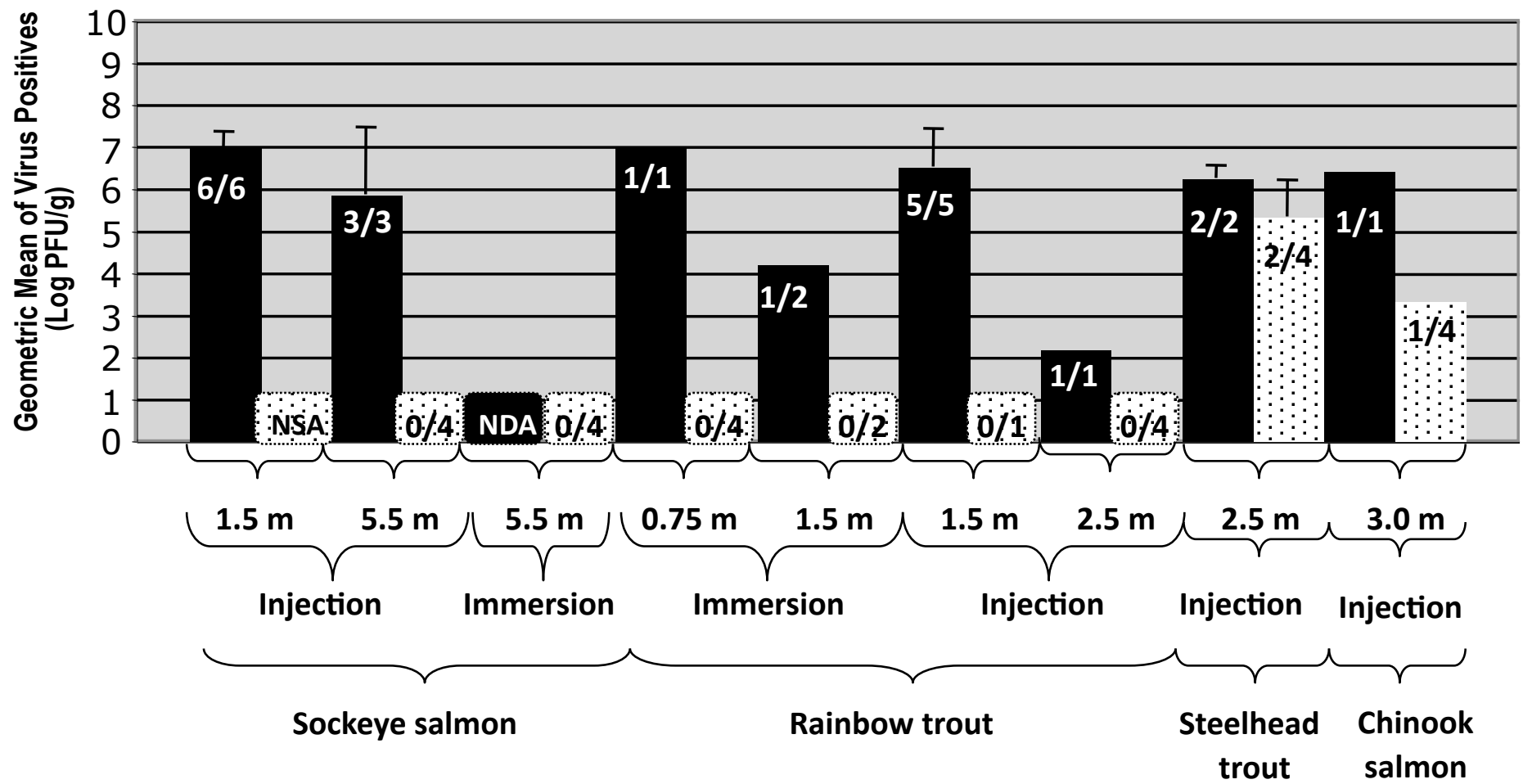
Fig. 6

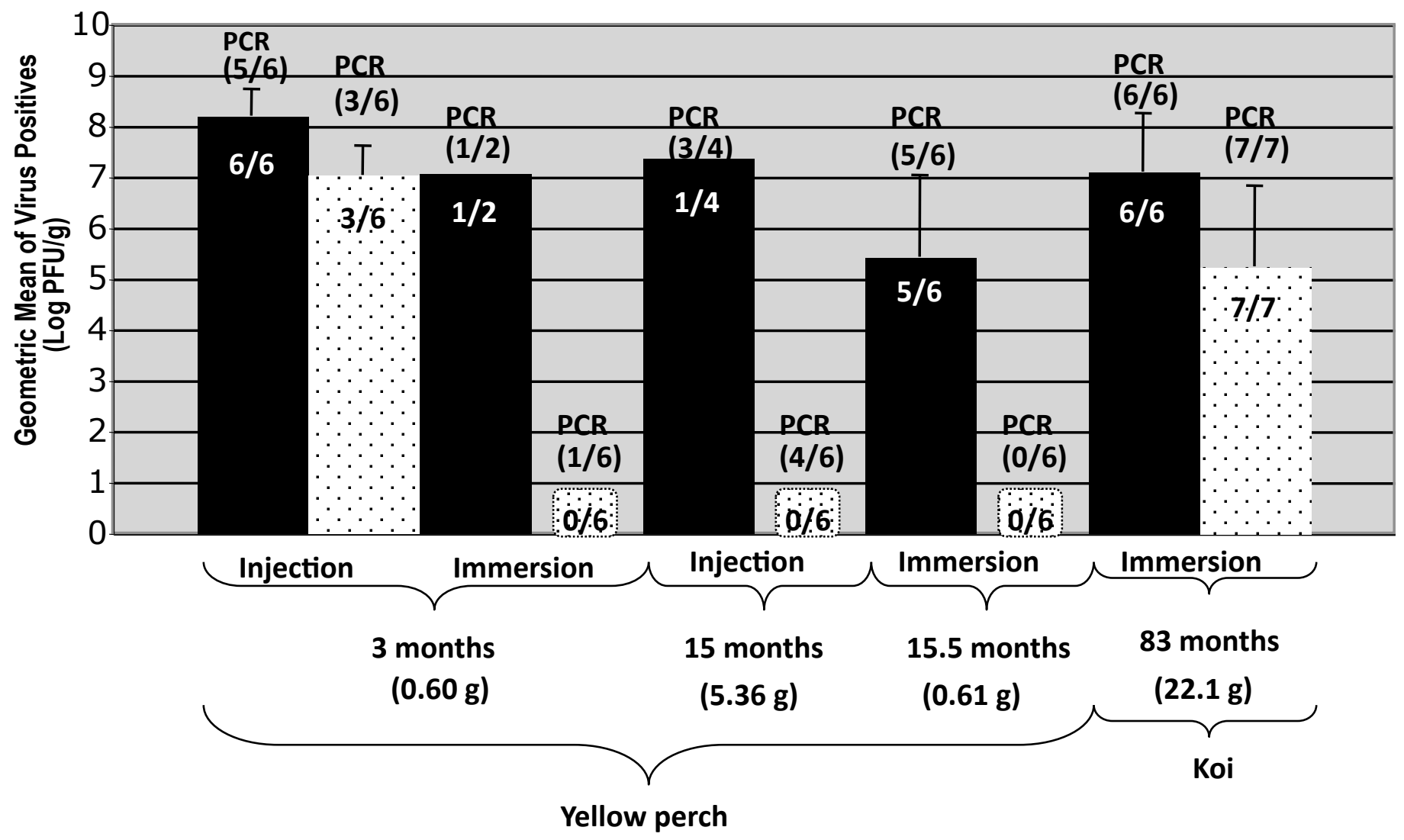


Table 1. Summary of salmonid, percid, and cyprinid species susceptibility to SVC disease.

\begin{tabular}{|c|c|c|c|c|c|}
\hline $\begin{array}{l}\text { Host } \\
\text { Species }\end{array}$ & $\begin{array}{c}\text { Figure }^{\mathrm{a}} \\
\text { (experiment) }\end{array}$ & $\begin{array}{l}\text { Challenge } \\
\text { Method }\end{array}$ & $\begin{array}{c}\text { Age } \\
\text { (months) }\end{array}$ & $\begin{array}{l}\text { Body } \\
\text { Weight } \\
\text { (grams) }\end{array}$ & $\begin{array}{l}\text { Cumulative } \\
\text { Percent } \\
\text { Mortality }\end{array}$ \\
\hline rainbow trout & $1 \mathrm{C}$ & Immersion & 0.75 & 0.10 & 5 \\
\hline rainbow trout & $1 \mathrm{~A}$ & Injection & 1.5 & 0.81 & 15 \\
\hline rainbow trout & $1 \mathrm{~A}$ & Injection & 1.5 & 0.81 & 40 \\
\hline rainbow trout & 1B & Injection & 2.5 & 1.4 & 5 \\
\hline steelhead trout & $1 \mathrm{C}$ & Injection & 2.5 & 0.80 & 10 \\
\hline sockeye salmon & 1B & Injection & 1.5 & 0.50 & 100 \\
\hline sockeye salmon & $1 \mathrm{C}$ & Immersion & 5.5 & 1.7 & 0 \\
\hline sockeye salmon & $1 \mathrm{C}$ & Injection & 5.5 & 1.7 & 5 \\
\hline Chinook salmon & 1B & Injection & 3.0 & 0.80 & 5 \\
\hline yellow perch & $2 \mathrm{~B}$ & Injection & 3.0 & 0.60 & 33 \\
\hline yellow perch & $2 \mathrm{~B}$ & Immersion & 3.0 & 0.60 & 2 \\
\hline yellow perch & $2 \mathrm{~A}$ & Injection & 15.0 & 5.4 & 4 \\
\hline yellow perch & $2 \mathrm{~A}$ & Immersion & 15.5 & 0.61 & 7 \\
\hline fathead minnow & 3 & Injection & 6.0 & 1.9 & 29 \\
\hline koi & $1 \mathrm{~A}$ & Immersion & 2.5 & 0.94 & 75 \\
\hline koi & $1 \mathrm{~A}$ & Injection & 2.5 & 0.94 & 100 \\
\hline koi & NF & Immersion & 3.5 & 1.4 & 75 \\
\hline koi & NF & Injection & 3.5 & 1.4 & 100 \\
\hline koi & 1B & Injection & 5.0 & 1.7 & 100 \\
\hline koi & $1 \mathrm{C}$ & Immersion & 11 & 2.2 & 70 \\
\hline koi & $1 \mathrm{C}$ & Injection & 11 & 2.2 & 100 \\
\hline koi & 3 & Injection & 18 & 3.5 & 95 \\
\hline koi & $2 \mathrm{~A}$ & Immersion & 83 & 22.1 & 11 \\
\hline
\end{tabular}

aFigure numbers for the mortality graphs associated with each fish species for every experiment are listed. $\mathrm{NF}$; no figure/mortality graph was generated for the 3.5 month old koi challenged with SVCV alone.

${ }^{b}$ Mean cumulative percent mortality for duplicate or triplicate tank replicates for each experiment treatment. 